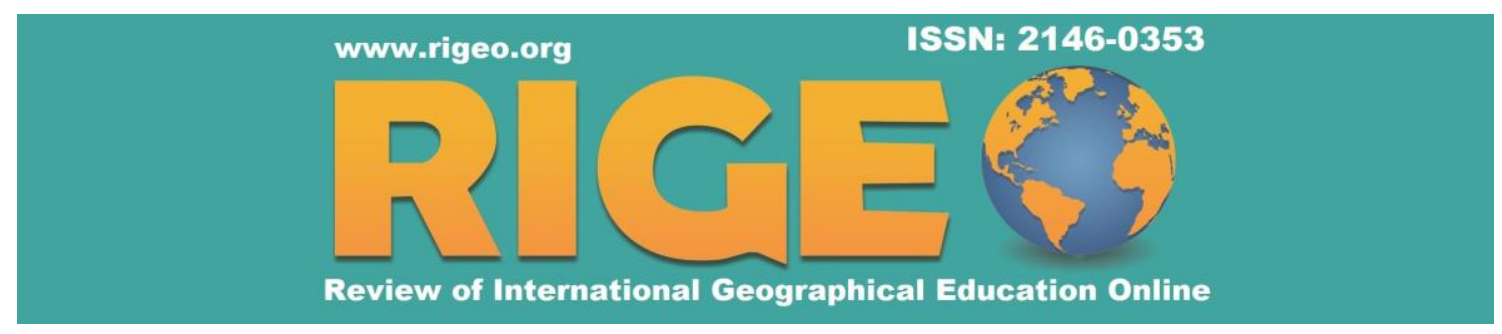

Review of International Geographical Education Online

(C) RIGEO Volume 9, Number 1, Spring 2019

To cite this article: Bozkurt, F. (2019). Evaluation of Geography Textbooks in Terms of Misconceptions about Climate Topic. Review of International Geographical Education Online (RIGEO), 9(1), 149-170. Retrieved from http://www.rigeo.org/vol9no1/Number1Spring/RIGEO-V9-N1-7.pdf DOI: $10.33403 /$ rigeo.573480

\title{
Evaluation of Geography Textbooks in Terms of Misconceptions about Climate Topic*
}

\author{
Fisun BOZKURT ${ }^{1}$ \\ University of Pamukkale, Denizli, TURKEY
}

\begin{abstract}
This descriptive study is centred on the representation of climate concepts in the geography textbook and academic books. The study mainly examined how the concepts, which were determined by considering the misconceptions in our previous studies, were presented in the $9^{\text {th }}$ grade newlypublished geography textbook and academic books. Also, the study identified, discussed and showed the ways in which the representation of climate concepts in the textbook might corroborate the students' misconceptions. Secondly, the misconceptions were examined by comparing how they were presented in local and foreign academic books. In addition, appropriate corrections, explanations and visual materials were presented to explain the conceptions. The findings show that the misconceptions or deficiencies mentioned in our previous studies still persist in the newly published textbook and local academic books. It is believed that such a study can help solve the problems related to the misconceptions encountered in geography teaching, and that it can increase the geography teachers', textbook writers' and publishers' awareness of the common misconceptions of the students about climate and thus it can shed light on the definitions and materials that can be used in describing these concepts.
\end{abstract}

Keywords

Climate; Misconceptions; Geography Textbook; Geography Education

In Turkey, geography is taught as an integrated course in primary and secondary schools (in grades 1-3 as a part of the Life Science Courses and in grades 4-7 as a part of Social Studies Courses). In high school, students take geography courses from 9 to 12 grades as an independent course. When compared to the ones handled in the courses called Life Science and Social Studies in the first seven years, geography lessons in

*This article is an updated the part of doctoral thesis of the author.

${ }^{1}$ Assist. Prof.; Faculty of Education, University of Pamukkale, Denizli, Turkey, e mail: fisunbozkurt [at] pau.edu.tr. ORCID: 00000001-9101-8422

(C) Review of International Geographical Education Online

RIGEO 2019

ISSN: $2146-0353$

www.rigeo.org 
high school are more complicated because of the concepts and terms, which were quite unfamiliar to a lot of students by then. Particularly, high school students come across some concepts and terms for the first time and while they learn, they are inclined to memorize them. Geography teaching programs are prepared to be taught for two hours weekly in grades 9 and 10, and 4 hours in grades 11 and 12. The course is thought to be compulsory in grades 9 and 10 for all High Schools and optional in grades 11 and 12 of science fields as well as in Science High Schools.

In the literature review it has been found out that there are some limitations in teaching geography such as insufficient content and practical course. The objectives and contents of the programs do not meet the requirements of this era for educating people, there are not any applied courses (Akınoğlu, 2004; Cohen, Manion and Morrison, 2004; Gökçe, 2009), the contents of the courses are heavy, and the allocated time is not enough (Akınoğlu, 2004; Sekin and Ünlü, 2002; Şahin, 2001, 2003, 2006). In a similar way, Turan (2002, p. 78) found that Geography I Course offerred during the first semester of the high school had 418 geography terms and concepts in it. His research revealed that it is not possible to teach those 418 geography concepts and terminology, to relate them with geographical facts and events, and to explain their causes, distribution, and results in just two hours a week. For instance, throughout the Climate Chapter, it is necessary for teachers to teach 120 terms and concepts and to get their students to understand atmospheric phenomena occurring all over the world in the framework of their causes, results, and distribution principles. The time allocated for this chapter in the yearly plan is only three weeks, which is just 6 hours. Turan indicates that it is even probable to increase the concepts upto 120 or more when we deal with the climate topic in a more detailed way (2002, p. 79-80). Additionally, Akşit (2007) stresses that the number of concepts could be increased upto 150 when the climate topic is addressed elaborately.

Moreover, a great deal of research indicates that in addition to many concepts, a lot of misconceptions appear in the Climate Topic (Akbaş and Gençtürk, 2011; Alkış, 2005, 2006; Başıüyük, Doğar, Gürses and Yazıcı; 2004; Coşkun, 2003; Doğar and Başıbüyük, 2005; Duman and Atar, 2004; Pınar and Akdağ, 2012). Previous studies on misconceptions in Turkey demonstrated that in all levels students experience difficulties in perceiving and understanding the climate chapter. In Turkey most of the research has been carried out on the misconceptions about global warming and greenhouse effects (Arsal, 2010; Bozkurt and Cansüngü, 2002; Demirkaya, 2008; Kahraman, Yalçın, Özkan and Aggul, 2008; Kılınç, Stanisstreet and Boyes, 2008; Kışoğlu, Gürbüz, Erkol, Akar and Akıllı, 2010; Ünlü, Sever and Akpınar, 2011). It is seen that in all levels the students and teachers have a great deal of misconceptions about this subject.

Furthermore, Gowda, Foxand and Magelky (1997) and Türkeş (1997, p. 36-37) indicated that the concepts such as weather, climate and climate change are inaccurately used. Another study on the conceptual misconception of climate was carried out by Henriques (2002). Henriques has brought together the misconceptions in those areas below: the properties of water, phase changes and the water cycle, cloud formation and precipitation, the atmosphere (gases), and greenhouse effect/global warming. Nelson, 
Aron and Francek (1992, p. 76) ran over various misconceptions concerning location, earth's hydrosphere, atmosphere; and lithosphere, which were handled with some explanations and corrections. Schneps and Sadler (1985) put forward that students hold a misconception by considering the Axial Tilt to be the "reason for seasons". American Association for the Advancement of Science (AAAS) (2007, p. 18) research showed that students at any ages (the college students as well) could believe that air implements force or pressure as long as it moves downwards. Rebich and Gautier (2005) noted that another misconception is that human activities lead to the greenhouse effect, which is like global warming. Similarly Khalid's (2001) study identified preservice elementary teachers' misconceptions about three environmental issues, which are the greenhouse effect, atmospheric ozone, and acid precipitation. Also McCaffrey and Buhr (2008) pointed out that the terms "greenhouse effect", "climate change" and "global warming" are used almost interchangeably among students and the general public and in the media as well. Many studies have been carried out on the fact that students' comprehension of climate is their confusing global warming with ozone depletion (Boyes and Stanisstreet, 1992; Chang, Pascua and Ess, 2018; Gowda et al., 1997; Gautier, Deutsch and Rebich, 2006). With the belief that the ozone hole enhances the greenhouse effect are related misconceptions such as on the type of radiation that is responsible for the excess amount of heat that is absorbed in the atmosphere. There is lack of understanding as to the basic processes of how the natural and the enhanced greenhouse effect operate (Chang et al., 2018). Boyes and Stanisstreet (1992) were among the first to draw attention to this. Boyes and Stanisstreet (1992) asserted that the students think in the following way: "Holes in the ozone layer play part in global warming since they allow increased penetration of solar heat". Boyes, Chambers and Stanisstreet (1995) claimed that a factor for this common misconception is that experimental learning is not possible in this field. This could be an essential point; yet, some physical processes which are significant for this complicated area of knowledge could be demonstrated through student experiments or teacher demonstrations (Hansen, 2003).

In addition, research studies have revealed that the textbooks used in schools include insufficient or sometimes inaccurate information (Román and Busch, 2015). Textbooks have also been criticized because of merely focusing on the descriptions of facts, rather than explanations with a particular focus on cause, condition, and consequence (Smolkin, McTigue and Yeh, 2011), promoting memorization instead of critical thinking (National Research Council 1990). Some of the problems associated with geography books include the facts that they are not produced by experts and are generally published for commercial purposes. It is essential that textbooks be scientific and contemporary concerning format and content, be consistent with geography teaching programs and enable students to participate actively, provide them with research skills, help them think critically, and supply a set of exercise books, guide books and CD ROMs (Gökçe, 2009; Demiralp, 2007). In this case, teachers provide students with sufficient information and precise conceptual understanding of these issues, which makes their role vital (Khalid, 2001).

One of the main purposes of climate education is to help students develop a scientific understanding about the Earth's climate system. In spite of an increase in supplementary 
educational materials and hands-on activities in the classrooms, teachers and students still use geography textbooks as the common source of scientific concepts (Choi, Niyogi, Shepardson and Charusombat, 2010). Students improve their understanding of scientific concepts based on their current ideas, in exactly the same way that scientists depend on their present knowledge base to get a better understanding about natural events (Bell, 2005; Choi et al., 2010). McCaffrey and Buhr (2008) pointed out that textbooks and traditional teaching materials with respect to climate science are mostly inadequate. Misconceptions, or deficiency of related earlier concepts, can prevent students from promoting an understanding of scientific concepts (Choi et al., 2010). It is important that the authors and publishers of textbooks are conscious of students' widespread misconceptions about climate topic while developing textbooks. Only in this way, their work can become an efficient tool to promote students' conceptual development and scientific understanding of the Earth's climate system.

A lot of climate education researchers have studied the conceptual understanding of students and teachers about climate topic and the impact of a variety of teaching strategies on teaching and learning the climate concepts. A small number of studies have centred on the representations of climate concepts that are found in the textbooks, though (Choi et al., 2010). The study addressed in this article tried to improve this situation by doing a careful examination of the representations of the climate concepts in geography textbooks and analyzing them to reveal their potential contributions to students' misconceptions about climate topic. Therefore, the current study is designed to answer the following questions:

1. How were the concepts, which were determined by considering the misconceptions in our previous studies (Akşit; 2007), presented (in terms of definitions, figures, analogies, and examples) in the $9^{\text {th }}$ grade newly-published geography textbook and academic books?

2. How were the concepts presented in local and foreign books in terms of assessment activities?

The teachers' consciousness about the misconceptions of these concepts while teaching this unit will also help to reveal the misconceptions in the students (Henriques, 2002). First, students' exposure to these concepts and then providing clear and reasonable corrections will bring forth the success. The appropriate use of physical models (Lightman and Sadler, 1988; Mattingly, 1987) and figures might be one of the certain strategies to achieve this purpose. Students can start holding a reasonably correct view of the world with new and correct explanations (Nelson et.al., 1992). The problems that result from the misconceptions in teaching geography could be referred to with the help of a study like this, and this would raise geography teachers, textbook authors and publishers' awareness about students' misconceptions. 


\section{Methods}

\section{Research Design}

Research is structured in a qualitative way. In this context, the method of document analysis, included in qualitative research methodology, was utilized.

\section{Data Collection Instruments and Process}

This study is centred on the representation of climate concepts, determined by considering the misconceptions in our previous studies (Akşit; 2007), and how they are presented in the $9^{\text {th }}$ grade geography textbook (Zaman, 2017). In other words, it aimed to examine whether the misconceptions put forward by us in 2007 still continue in newly-published textbooks and academic books after 11 years. The textbook was published and distributed to all over the country as the single course book by the Ministry of National Education in 2017. Therefore, only one textbook was examined. Secondly, the misconceptions were examined by comparing how they were presented in local (physical geography and climatology) academic books which were picked based only on their common use in Turkey [Akengin and Dölek; 2013; Atalay, 2013; Doğanay and Sever, 2011; Erol, 2011] and foreign academic books [Ahrens, 2012; Hess and Tasa, 2013; Strahler, 2013]. For instance, the study identified, discussed and showed ways in which the representation of the climate concepts in the book might corroborate the students' misconceptions. In addition, appropriate corrections, explanations and visual materials were presented to explain the conceptions. The study did not include any intended or inferred evaluation, assessment, judgment, or promotion of the worthiness or correctness of any one textbook stated in this article. Especially in the study, the textbook was analyzed for the presentation of each scientific concept, (in terms of definitions, figures, analogies, examples and assessment activities).

Also, educational research databases such as Educational Research Information Center (ERIC), Google Scholar were searched for the articles related to middle school, high school and university students' misconceptions about climate topic in order to create the conceptual framework of the study. The literature was reviewed and the misconceptions about climate were collected. In this process, 14 articles in total were reviewed in order to find out the common misconceptions of the students about the climate topic and they were included in the examination list. According to the literature and our previous studies it has been examined 10 misconceptions in the textbook and academic books have been examined in the current study (Table 1). In this study, the concepts given in the list as misconceptions are not completely wrong, but some of them are limited or incomplete definitions that are also listed under the title of misconception, too. The lists were externally reviewed by three experts. Two of them are experts in physical geography and one of them is an expert in climatolgy. 
Table 1

Categories, Misconceptions and Literacy Principles

\begin{tabular}{ll} 
Categories & Misconceptions \\
\hline $\begin{array}{l}\text { The presentation of } \\
\text { each scientific } \\
\text { concept in the }\end{array}$ & $\begin{array}{l}\text { Distinction between weather } \\
\text { and climate }\end{array}$ \\
$\begin{array}{l}\text { textbook and } \\
\text { books }\end{array}$ & $\begin{array}{l}\text { Confusion about the } \\
\text { definition of variable gases }\end{array}$
\end{tabular}

Insufficient definition of Ozone in terms of locations

Literacy Principles

Climate not only covers average state but it also contains extreme values and all statistical changes

In the entire atmosphere, the complete amount of water vapor stays nearly the same. Thus, it's listed as a "variable gas" which means that it's variable in location.

Ozone in the upper atmosphere is beneficial because it protects life on the surface of Earth from the sun's damaging ultraviolet radiation. However, ozone is an air pollutant that harms and aggravates the lung tissue in the lowest layers of the atmosphere.

Incorrect explanation about The maximum temperature may happen at a the warmest part of the day time between 2:00 and 4:00 p.m.

Some incorrect information about the topic of atmospheric pressure

Insufficent definition of Coriolis Effect

High and low pressure should be employed to describe relative conditions-pressure that is higher or lower compared to that of the nearby areas.

Carioles effect has an important influence on the direction of wind flow. The Carioles effect is caused by the rotation of the Earth and the inertia of the mass experiencing the effect, in a reference frame with clockwise rotation, the deflection is to the left of the motion of the object; in one with counter-clockwise rotation, the deflection is to the right. Deviation direction appears to the right in the Northern Hemisphere and to the left in the Southern Hemisphere. But here, this fact only applies to high pressure areas; low pressure areas have the opposite feature.

Confusion about the definition

of greenhouse effect

Distinction between global warming and climate change

The atmospheric effect is called the greenhouse effect incorrectly. This incorrect naming indicates that the greenhouse is heated by the same processes as the atmosphere.

Global warming is the name given to an expected increase in the magnitude of the greenhouse effect. Climate change encompasses the many effects of warming.

Confusion about the influence of ozone on the greenhouse effect and global Ozone is indeed a greenhouse gas, but its influence on the greenhouse effect and global warming 
Confusion about the impact of the ozone hole on climate change
UV waves that do reach the surface mostly impinge upon snow and ice, ensuring that virtually no surface warming occurs. Therefore, the depletion of ozone over Antarctica during its spring (that is, the ozone hole) does not enhance global warming at the earth's surface

\begin{tabular}{|c|c|}
\hline $\begin{array}{l}\text { Comparison of } \\
\text { Climate Chapter of } \\
\text { books in terms of } \\
\text { figures }\end{array}$ & $\begin{array}{l}\text { Quality of figures } \\
\text { Paper quality } \\
\text { Print quality } \\
\text { Coloring }\end{array}$ \\
\hline $\begin{array}{l}\text { Comparison of } \\
\text { Climate Chapter of } \\
\text { books in terms of } \\
\text { assessment } \\
\text { activities }\end{array}$ & $\begin{array}{l}\text { Whether the key concepts } \\
\text { are included } \\
\text { Whether the abstract is given } \\
\text { Question types } \\
\text { Reading parts }\end{array}$ \\
\hline
\end{tabular}

\section{Data Analysis}

In the study document analysis was utilized. Document analysis refers to a systematic procedure employed to review or evaluate both printed and electronic (computer-based and Internet-transmitted) documents. Similar to other analytical methods used in qualitative research, document analysis involves the examination and interpretation of data in order to obtain meaning, get a clear understanding, and increase empirical knowledge (Corbin and Strauss, 2008). Which documents are important and can be used as a data source is closely related to the research problem. For example, in a study related to education, such documents can be used as a data source; textbooks, curriculum instructions, school correspondence and records, student records, guidance records and files, meeting minutes, student assignments and exams, unit plans, official documents related to education and so on (Yıldırım and Şimşek, 2013).

\section{Findings and Discussion}

The next section describes misconceptions detected in our previous studies (Akşit; 2007) and our examination of the representations of the climate concepts in newlypublished textbook and local books. In this study, a number of misconceptions associated with the climate topic, such as climate and weather, atmosphere and gases, variable gases, ozone layer, the warmest part of the day, atmospheric pressure, and coriolis effect, "greenhouse effect", "global warming", "climate change" and "influence of ozone and ozone hole on climate change" are discussed with appropriate corrections and explanations. Findings are presented below in comparison with the literature.

\section{Findings about How the Concepts, Which Were Determined by Considering the Misconceptions in Our Previous Studies (Akşit; 2007), Were Presented (In Terms of Definitions, Figures, Analogies, and Examples) In the $9^{\text {th }}$ Grade Newly-Published Geography Textbook and Academic Books}

Climate and weather. Türkeş (1997, p. 36-37) remarked that the concepts of weather, climate and climate change are used inaccurately in the press releases, compilations, translations and programmes about climate every year, particularly during the periods when colder, rainier and more stormy, or on the contrary, hotter, more arid 
(could sometimes be really humid) and calmer weather conditions than usual are effective for an extended period of time. Türkeş (1997, p. 37) defined the concepts of air and climate as follows: "The weather is the short-term state of the atmospheric conditions at any place and time. This moment of the atmosphere, that is air, is explained by the coexistence of many variables such as temperature, rain... anywhere on the earth." Still, as Türkeş stated the climate not only covers average state but it also contains extreme values (extremities) and all statistical changes. For example, in a region where the winters are harsh, it can follow a cold winter season with a warm winter season. In a region where summer drought is regarded as a normal climatic characteristic, it is possible to experience a humid and cool summer next year. Or, in a semi-arid climate region where annual average precipitation is not high, precipitation that is close to the average annual precipitation can fall in a few days as a result of heavy spring precipitation. That is why the term climate should also include the extractions recorded due to the weather anomalies mentioned above and their probability of statistical formation. This statistical approach has been integrated in recent years with the term climate and climate has begun to be defined in the form of a synthesis characterized by long-term statistics such as variance and mean values of atmospheric variables, weather conditions in a given area. Undoubtedly, the synthesis term in the new definitions provides more than what the average term covers.

Hess and Tasa $(2014$, p. 67) clarified the concepts of climate and weather by underlining the difference between them. Weather is the term which refers to short-term atmospheric conditions for a particular time period in a certain area. It is a total of temperature, humidity, cloudiness, precipitation, pressure, winds, storms and other atmospheric variables over a short period of time. Therefore, we can refer to the weather of the moment or the week or the season, or maybe even of the year or the decade. Weather is the change of a permanent pattern, sometimes in an irregular way. But in the long run, variations can be generalized into a composite picture, which is referred as climate. Climate is the sum of daily weather changes over a long period of time. It encompasses the common features, and the variations and extremes, as well. The weather information of a long period, mostly several decades at least, is needed to define the climate of an area. The concepts of weather and climate are related but they don't have the same meaning. The difference between instant details and long-term generalities forms the distinction between weather and climate.

In the textbook and a number of geography books, the fact that climate has been explained incompletely has been criticised in the literature. None of them mentioned the variations and extremes. Therefore, they may reinforce students' misconceptions. The definitions in the textbook and the books are as follows:

"The average weather conditions that are effective for many years in large areas are called climate... The weather is short-term and suddenly changeable, while the climate is the long-term average of weather conditions. " (Zaman, 2017, p. 109)

"Climate is the average weather conditions which are observed for many long years anywhere on earth" (Akengin and Dölek, 2013, p. 129; Doğanay and Sever, 2011, p. 216; Erol, 2011, p. 10). 
"Weather conditions which are effective in a certain field for a short period of time is called weather forecast. The period (time) at issue here is a few hours at least and a few days at most." (Doğanay and Sever, 2011, p. 216.)

There are also explanations on the duration of the weather in the textbook and some local sources which contradict foreign sources. For example: while the textbook and some local sources state that the period (time) of the weather at issue could be a few hours at least and a few days at most (Doğanay and Sever, 2011: 216; Zaman, 2017, p. 109), some foreign sources state that the moment, the week or the season, or maybe even the year or the decade could be the issue for the weather (Hess and Tasa, 2014, p. $67)$.

Atmosphere and gases. In the textbook (Zaman, 2017, p. 105-106) some figures may reinforce students' misconceptions. For example; the thickness of the atmosphere is greatly exaggerated in Figure 1, and it is not known what the white color between the earth and the atmosphere means. Moreover, the fact that the proportion of the gases is given on the figure can make it difficult to understand that the atmosphere is a mixture of these gases. Air - mostly used as an alternative word for atmosphere - is not a single gas, yet a mixture of gases, primarily nitrogen and oxygen. For this reason, it would be more accurate to write the rates next to the figure rather than on the figure. In the other image (Figure 2) related to the density of the gases, the gases gradually decrease as they move upper part of the atmosphere. However, when we look at Figure 2, which is taken from the textbook, it cannot be seen that $98 \%$ of the density is concentrated in the lower layers of the atmosphere. Therefore Figure 3 and 4 could be better illustrations to explain air pressure and air density wich decline with growing altitude.

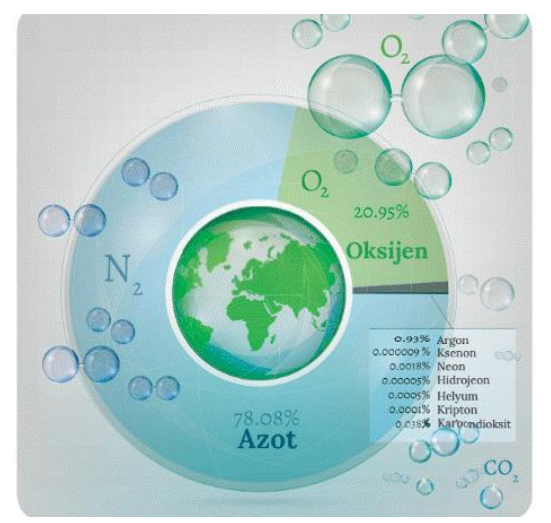

Figure 1. Proportion of the gases in the atmosphere (Zaman, 2017, p. 105)

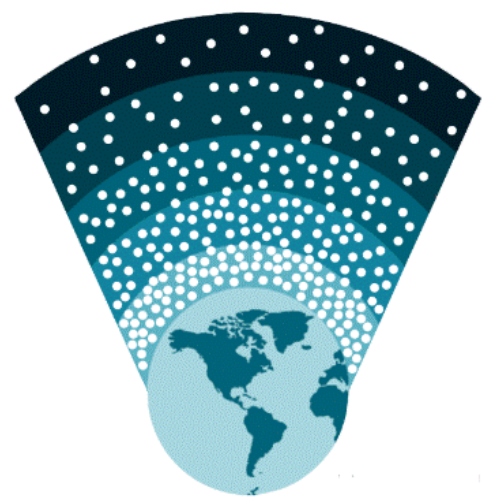

Figure 2. Density of the gases in the atmosphere (Zaman, 2017, p. 106) 
In books, more concrete explanations and figures should be given to eliminate misconception (such as Figure 3 and 4). In addition, in Figure 3, an example is given from students own environment (the highest peak of North America, Mount McKinley in Alaska) to make an abstract concept more concrete and understandable. In Figure 4, the relationship between pressure and altitude is visualized by the density of gas molecules.

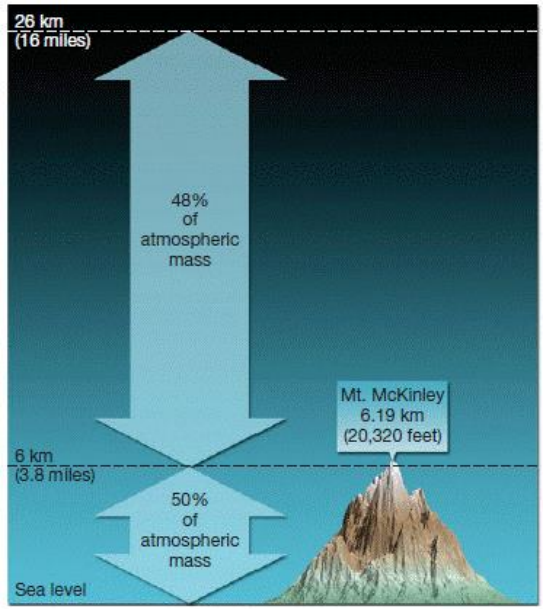

Figure 3. Most of the atmospheric mass is close to Earth's surface. More than half of the mass is below the highest point of Mount McKinley (Denali), North America's highest peak (Hess and Tasa, 2014, p. 59).

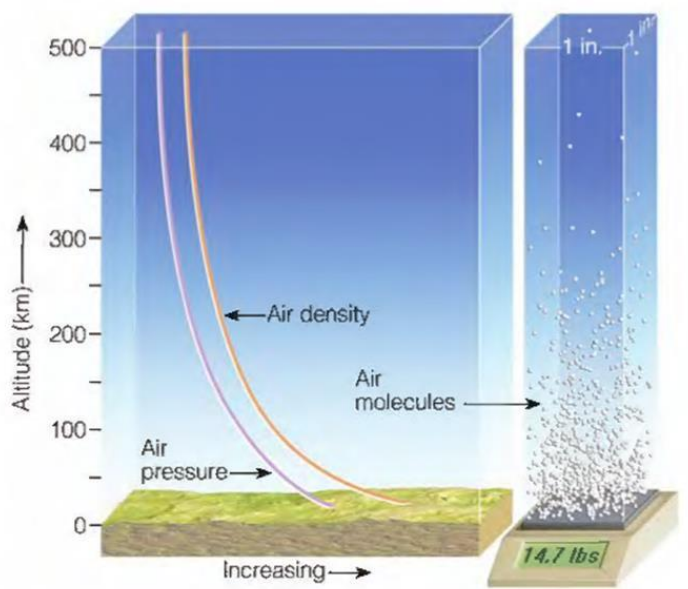

Figure 4. Both air pressure and air density decline with growing altitude. The heaviness of the entire air molecules on the earth's surface produces an average pressure near $14.7 \mathrm{lb} / \mathrm{in}^{2}$ (Strahler; 2012, p. 10).

In an academic book, Akengin and Dölek stated (2013, p. 134 Figure 5.3) heavy gases gathered on the lower layers of the atmosphere due to the effect of gravity and the light gases did so, on the upper layers. Gases become increasingly rare as they go up and a gas particle in the Exosphere travels for a few kilometres before it meets and collides with another one. According to this information gases should have formed layers according to their weights. However, it should be emphasized that the pure chemical composition is steady especially in dry air below $80 \mathrm{~km}$, and that the concentration of important components does not always change in principle while the components of the atmosphere is told in this subject. The main gases of the atmosphere display a homogeneous vertical distribution throughout the lowest 80 or so kilometers of the atmosphere. This area of uniform composition is called the homosphere. The sparser atmosphere above this zone does not show such homogeneity; instead, the gases are layered in compliance with their molecular or atomic weights. This higher zone is referred as the heterosphere (Hess and Tasa, 2014, p. 61).

Variable gases. In the textbook and some of the local books' explanation of the variable gases in the atmosphere may cause misunderstanding. For example:

"Gases which are always present in the atmosphere and the rates of which change water vapor and carbon dioxide. The rate of water vapor, which is very rare in the atmosphere, varies with time and place." (Zaman, 2017, p. 105). 
"Water vapor is undoubtedly the gas, whose amount in the air changes most, considering the location and time...." (Erol, 2011, p. 10).

Hess and Tasa (2014, p. 57) stated that in this respect, while the components of the atmosphere are described, it should be emphasized that in dry air below $80 \mathrm{~km}$ the pure chemical composition is regular and the concentration of the important components does not always change. In the entire atmosphere, the complete amount of water vapor stays nearly the same. Thus, it's listed as a "variable gas" which means that it's variable in location. Water vapor is most abundant in air which covers warm, humid places like tropical oceans, where water vapor may reach upto $4 \%$ of the total volume; whereas the amount of water vapor is really a small fraction of $1 \%$ in deserts and Polar Regions.

Ozone layer. Another widespread misconception is about ozone layer. In the textbook, ozone, no matter where it's located, is not identified as good or bad. The following points should be emphasized so as to prevent misconceptions while teaching this topic:

"Almost $90 \%$ of all the atmospheric ozone is located in the ozonosphere. This ozone is considered "good" because it absorbs certain wavelengths of solar radiation (The other 10 percent of ozone occurs in the troposphere and is "bad")." (Hess and Tasa, 2014, p. 63).

Moreover, in this subject it should be addressed that the ozone layer is not just composed of ozone in spite of its name. It takes its name because of the maximum concentration of ozone compared to other gases (Hess, 2012, p. 61-62).

The warmest part of the day. In the textbook there is an incorrect explanation about the warmest part of the day:

"The warmest time of the day is usually between 12.00 and 14.00 p.m. according to local time due to heat accumulation" (Zaman, 2017, p. 113).

"The highest daily temperature, however, comes after two hours of noon" (Atalay, 2013 , p. 54), which means that the sun's rays rise perpendicular to the surface or rise above the horizon. So the temperature typically peaks between 2 and 4 p.m. (Strahler, 2013, p. 117). Similarly, Ahrens (2012, p. 55) explains this situation as follows:

"The maximum temperature may happen at a time between 3:00 and 5:00 p.m. where the sky remains cloudless all afternoon in summer. Where there is cloud or haze in the afternoon, it takes place one or two hour earlier."

Atmospheric pressure. There is some incorrect information about the topic of atmospheric pressure in the textbook and academic geography books such as the following:

"Normal air pressure is described as the air pressure which keeps the height of mercury column at $760 \mathrm{~mm}(1013 \mathrm{mb})$ at $15^{\circ} \mathrm{C}$ temperature, $45^{\circ}$ north latitude, at sea level." However, in the foreign literature, this is described as "standard pressure" (Strahler, 2013, p. 151). A number of local books have also included such inaccurate information "When the value of the pressure is higher than $1013 \mathrm{mb}$, it is called highpressure, while the pressure value that's lower than $1013 \mathrm{mb}$ is called low-pressure" 
(Akengin and Dölek, 2013: 145; Atalay, 2013: 105; Doğanay and Sever, 2011, p. 229230; Erol 2011, p. 112). In fact, high and low should be employed to describe relative conditions-pressure that is higher or lower compared to that of the nearby areas. It is essential to take account of the relative nature of pressure measurement (Hess and Tasa, 2014, p. 112).

One of the widely-adopted notions is that atmospheric pressure is the weight of the atmosphere descending upon the surface of the earth because of gravity (Henriques, 2002; Nelson, Aron and Francek, 1992). Because the pressure applied at any particular atmospheric level is mainly owing to the weight of the upper air, this notion should not certainly be considered incorrect. Still, the problem occurs when one, by mistake, comes to a conclusion that this force acts only downwards. Actually, the main pressure gradient force in the atmosphere continuously acts upwards, which is opposed and balanced by the force of gravity. This force is basically equal in all directions at any point in the atmosphere. Along with this understanding, it is not difficult to apprehend the strong upward pressure gradient of the atmosphere (Nelson et. al., 1992, p. 78).

Coriolis effect. Another misconception involves Coriolis Effect. The textbook and some local books inaccurately describe it as follows;

"Winds depending on daily movement, deviate towards right in the Northern Hemisphere and left in the Southern Hemisphere" (Zaman, 2017, p. 120 and 123).

"...Deviation moves towards right in the Northern Hemisphere and left in the Southern Hemisphere" (Akengin and Dölek, 2013, p. 150; Atalay, 2013, p.110; Doğanay and Sever, 2011: 230). But here, this fact only applies to high pressure areas; low pressure areas have the opposite feature (Hess and Tasa, 2014, p. 114). Unfortunately, there isn't any explanation in which this phenomenon occurs in high pressure areas or low pressure areas in the text of the books. To avoid misunderstandings, this information should be explained more clearly in the text of the books. In a cyclone, low pressure is at the center, so the pressure gradient is straight inward. In an anticyclone, high pressure is at the center, so the gradient is straight outward. But because of the rightward Coriolis force and friction with the surface, the surface air moves at an angle across the gradient, creating a counterclockwise inspiraling motion and a clockwise outspiraling motion. In the southern hemisphere, the cyclonic spiral will be clockwise because the Coriolis force acts to the left. For anticyclones, the situation is reversed (Figure 5) (Strahler, 2013, p. 159).
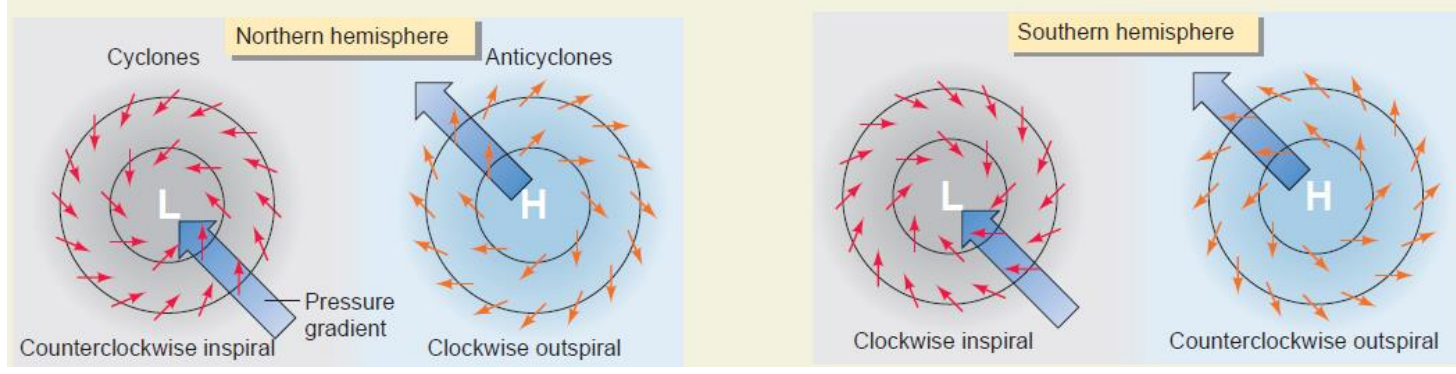

Figure 5. Air motion in cyclones and anticyclones (Strahler, 2013, p. 159) 
One incident that the Coriolis Effect does not seem to influence is the circulation pattern of water that flows away out of a basin or bath. A folk tale suggests that Northern Hemisphere sinks drain water in a clockwise direction while Southern Hemisphere sinks follow a counterclockwise pattern. The time elapsed is so short, and the velocity of the water is so slow that the coriolis effect cannot be put forward to give satisfactory explanations for these movements - whereas the features of the plumbing system, the shape of the washbasin, and merely chance are more probable to establish the flow patterns (Nelson et al., 1992, p. 78; Hess and Tasa, 2014, p. 73).

The greenhouse effect. One of the common misconceptions is that the terms "greenhouse effect", "global warming", "climate change" and "influence of ozone and ozone hole on climate change" are absent or their differences are not mentioned in the majority of the reviewed books and textbook (Akengin and Dölek, 2013; Doğanay and Sever, 2011; Erol, 2011; Zaman, 2017). For example there is some incorrect information about the topic of greenhouse effect in one of the books (Akengin and Dölek, 2013, p. 175-176) as the following:

"...However, with the increase in the amount of these [greenhouse] gases, long-wave radiation is kept more and the atmosphere and the earth become more heated. This phenomenon is known as the greenhouse effect of the atmosphere."

One of the misconceptions about the atmosphere is determined to be related to the "greenhouse effect" by Nelson et al. (1992, p. 78). Most of the solar energy passes through the atmosphere and reaches the earth and is absorbed. The world re-emits energy. Most of the energy from the earth is absorbed by atmospheric water vapor, water drops, carbon dioxide and dust. This process is known as the atmospheric effect and is called the greenhouse effect incorrectly. This incorrect naming indicates that the greenhouse is heated by the same processes as the atmosphere. This misunderstanding means that the greenhouse glass passes short-wave rays but absorbs back the reflected long-wave rays. The only function of the glass in the example here is to prevent heat dissipation. But the functions of the atmosphere in the warming of the world are a lot more and more complex (Fraser, 2007). In addition this warming trend became known to the public as global warming, although many climate scientists prefer the more general term climate change because it encompasses the many effects of warming, such as changes in precipitation patterns (Hess and Tasa, 2014, p. 86-104).

Ozone and the Ozone Hole: Their influence on climate change. Ahrens stated that (2012) Ozone is indeed a greenhouse gas, but its influence on the greenhouse effect is just minor because of the following two conditions: (1) The concentration of atmospheric ozone is extremely small, (2) Ozone only absorbs infrared energy in a very narrow band. Therefore, any small change in ozone concentration would have a negligible impact on the greenhouse effect and climate change. Another question about the impact of the ozone hole on climate change is about how the ozone hole affects climate change. Ahrens (2012, p. 42) stated that " $U V$ waves that do reach the surface mostly impinge upon snow and ice, ensuring that virtually no surface warming occurs. Therefore, the depletion of ozone over Antarctica during its spring does not enhance global warming at the earth's surface." 


\section{Comparison of Climate Chapter of Books in Terms of Figures Used}

The subjects in the textbook and local books are not generally explained by giving a cause and effect relationship and they are mostly presented with short generalizations and simple visuals. It is observed that the local books, compared to the foreign ones, are insufficient in terms of images, that most of them are printed in black and white, and that the paper, cover and print quality are not good, either. For example: In the following images (Figure 6) taken from the textbook, the relations between pressurealtitude, pressure-temperature, pressure-density, pressure-gravity are tried to be expressed with simple graphs (Zaman, 2017, p.119-120).

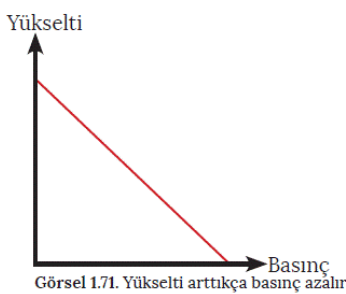

(a)

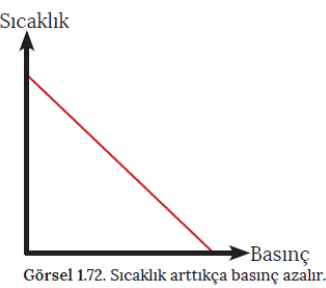

(b)

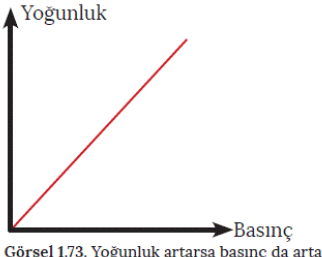

(c)

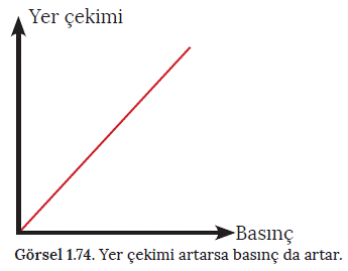

(d)

Figure 6. Factors affecting pressure: (a) The pressure decreases as the altitude increases; (b) The pressure decreases as the temperature increases; (c) The pressure increases if the density increases; (d) The pressure increases if the gravity increases (Zaman, 2017, p. 119-120).

In the textbook the relation of pressure with temperature and density is not explained well and the images used are insufficient. This kind of narrative style made without a cause-effect relationship, will lead students to memorize without questioning and understanding the reason.

Unfortunately, local academic books are insufficient to use the illustrations, either. For example: an academic book which is for higher institutions, has illustrations about vertical structure of the atmosphere and density of the gases in the atmosphere which are too simple for the level (Figure 7 and 8) (Akengin and Dölek, 2013, p. 132, 134).

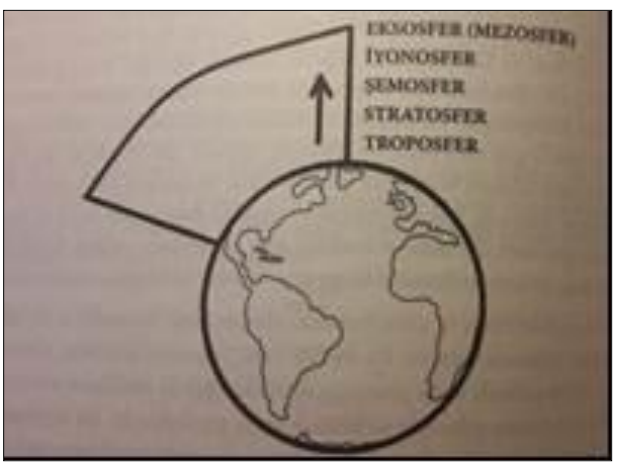

Figure 7. Layers of atmosphere according to physical and chemical properties of the gases (Akengin and Dölek, 2013, p. 132).

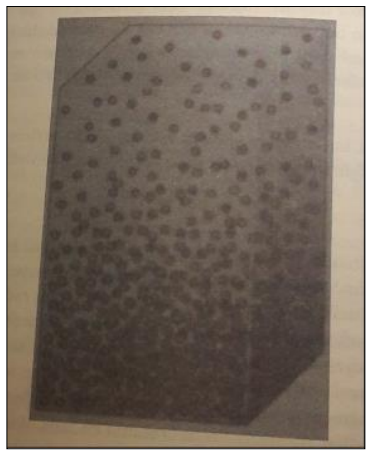

Figure 8. Heavy gases gathered on the lower layers of the atmosphere due to the effect of gravity and the light gases did so on the upper layers (Akengin \& Dölek, 2013, p. 134). 
Same topic explained with more concrete explanations and figures in Hess and Tasa's book $(2014$, p. 60, 61). Figure 9 and 10 are good illustration to explain the relationship between pressure and altitude. Besides, all figures have been used to explain the subject and have been associated with the narration in the text in this book. Such as:

"Atmospheric pressure can be thought of, for simplicity's sake, as the "weight" of the overlying air. The taller the "column of air" above an object, the greater the air pressure exerted on that object, as Figure 9 shows...” (Hess and Tasa, 2014, p. 59).

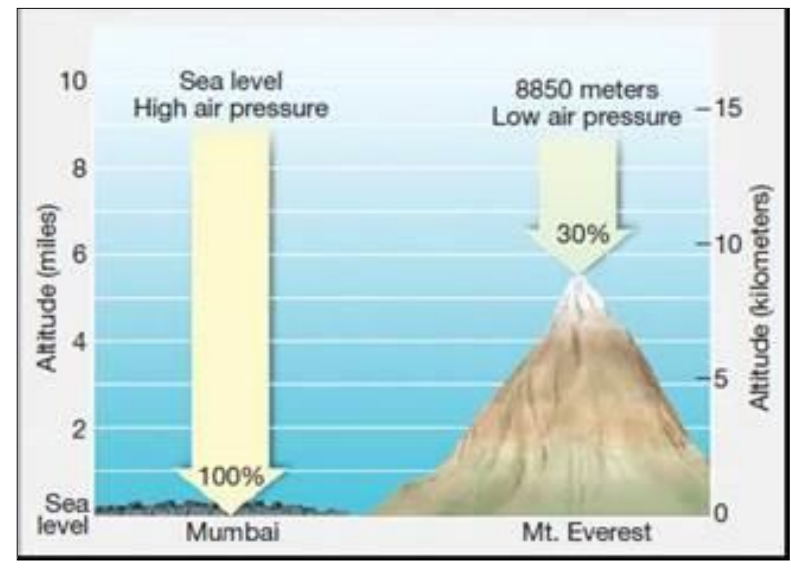

Figure 9. Atmospheric pressure is highest at sea level and diminishes rapidly with increasing altitude (Hess and Tasa, 2014, p. 60).

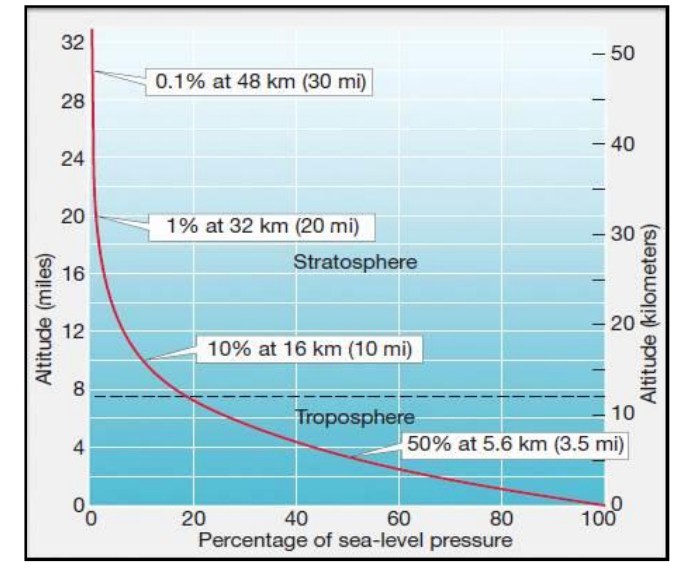

Figure 10. Air pressure decreases with increasing altitude, but not at a constant rate (Hess and Tasa, 2014, p. 61).

As an example Figure 11 is a better illustration to explain thermal structure of the atmosphere than Figure 7. As shown in Figure 11 (Hess and Tasa, 2014: 59), the vertical pattern of temperature is complex, comprising a series of layers where temperature decreases and increases alternately. Also it can be seen clearly that names and altitude of the atmosphere layers from the figure. The visuals used in textbooks perform functions such as helping to comprehend the content, drawing attention, motivating, and explaining abstract and complex concepts. Since visual elements contain intensive information, they make it easy for students to understand, remember and use what they have read, and attract attention. In addition, the text should refer to visual elements and the visuals should support the text directly. For this reason, visual elements used in textbooks should be designed in an appropriate, creative, directive, thought-provoking, message-summarizing and informative way. However, it was observed that visual elements were not sufficiently included in the textbooks examined, and visual elements did not contribute to message transfer. 


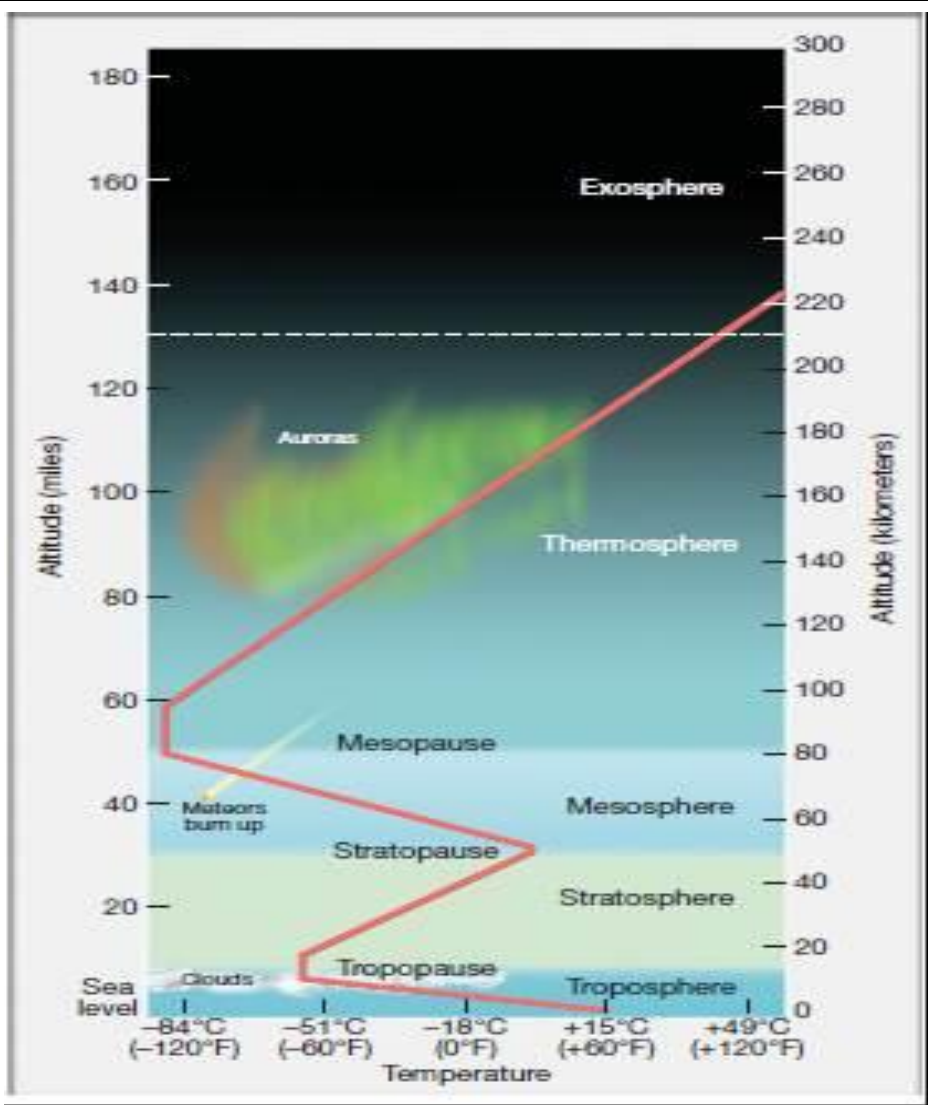

Figure 11. Thermal structure of the atmosphere (Hess and Tasa, 2014, p. 59).

\section{Findings about How the Concepts Were Presented in Local and Foreign Books in Terms of Assessment Activities}

In foreign books, after studying each chapter brief reviews, review questions (and also questions for thinking and exploring), essay questions, summary and key terms are given. Key terms from each text section are shown in bold type. Definitions for key terms are also found in the glossary at the back of the book. Also, resources included by animations, videos, simulations and interactive exercises are given in some foreign books (Such as Strahler, 2013; Hess and Tasa, 2014). The students are also given opportunities to relate what they have learned to daily life with the reading texts at the end of the subjects in foreign books. For example: although the properties of the atmosphere are included in the area of many sciences, the natural interaction between the environment and human which is the main purpose of geography is emphasized by the reading texts. In addition, the climate topic is given with experiments, maps, pictures, graphs, tables, reading texts such as focus on a special topic and focus on environmental issues, remarkable explanations such as Did You Know? parts or reallife examples in foreign books.

Unfortunately, the only thing at the end of the chapter in the local academic books is references. Similarly, in his study on geography books, Atalay (2004) states that the authors do not follow the current literature and they are not sufficiently aware of the foreign sources; he also states that a narration based on depiction is dominant in books 
and those books are not able to describe the conditions of the natural environment adequately and that there is not enough relation between the natural environment-human interaction. Unfortunately, these criticisms are still valid for newly published books.

\section{Conclusion and Suggestions}

In this research it has been found that representation of climate concepts in the textbook and local geography books are still problematic. The subjects in the textbook and local books are not generally explained by giving a cause and effect relationship and they are mostly presented with short generalizations and simple visuals. It is also observed that the local books, compared to the foreign ones, are insufficient in terms of images. Most of the local books are printed in black and white because of using straw paper, so the paper, cover and print quality are not good, either. Economical reasons can be said to be effective here. However, books should be prepared with high quality paper, covering, binding and printing techniques. The fact that the paper quality is not very good in the local books and that the images are black and white reduce the book's charm. In addition, summary, key terms, effective assessment, real-life examples, reading texts and online resources and references should be included in the chapter as a learning review.

There are always many misconceptions in physical geography teaching. Such studies that focus on the misconceptions may raise awareness for the authors of the textbooks, publishers and the teachers to overcome the misconceptions about the subject. Awareness of these misconceptions could be of great help to reveal the students' misconceptions. Success can be achieved by uncovering them in the first place, and then by providing clear and rational corrections of these. Appropriate visuals, models, experiments and map applications can be used to make this abstract subject concrete in geography textbooks and books. Also, correct explanations will help students gain a logical and accurate world view (Mattingly, 1987; Lightman and Sadler, 1988; Nelson et.al., 1992; McCaffrey and Buhr, 2008).

Most teachers do not have enough time to gather data about misconceptions from their students or from the research. If teachers are provided with a list of topic related misconceptions, they can review the list while they are planning instruction in order that lessons which challenge students' ideas could be created. These lists, like the one given in this paper, act as useful information for practicing teachers, as well as for preservice teachers (Henriques, 2002).

When deciding on how and what concepts should be presented to students, during the writing process of scientific books and textbooks, they should carefully consider the common misconceptions of the students about climate. False or commonly confused concepts should be explained separately and the differences should be emphasized. In this process, scientists, educators, and publishers should communicate with each other about their knowledge and perspectives on climate science and pedagogically appropriate teaching approaches (Choi et. al., 2010).

It should be noted that textbooks are the basic teaching tools for students. Textbooks complete the oral course of the teacher, make it possible to review the information, 
make the student more active while studying from the book, offer different types of questions, solutions and information, prepare the student for the course in advance, and most importantly provide the student with the opportunity to repeat the subjects they haven't understood well at their own pace at any time. For this reason, it is inevitable that explanations and definitions should be correct and well organized.

In this study the analyzed textbook is taught as the only textbook in the whole country. The use of a single textbook and free distribution of it can help to ensure unity in teaching. However, in 1949, the single book practice was terminated due to the fact that it directed the students to memorize, kept them away from inquisitive perspective, narrowed their horizons, and prevented the writing of better pedagogical books because of the absence of a competitive environment. Today, returning to the single book practice will cause the problems addressed beforehand to be repeated. It will also lead to a one-way information presentation. The increase in the quality of textbooks can only be provided by giving the opportunity to write and read more books. Artvinli (2009) have revealed that classroom teaching is mostly determined by the content of textbooks in Turkey, and that teachers carry out many activities from textbooks in the class. Since the textbook is the basic material of both the teacher and the student, it significantly contributes to the quality of teaching as well. Therefore, it is essential that textbook authors and publishers are aware of the common misconceptions of the students about climate topic while developing textbooks so that they can be efficient tools to promote students' conceptual development and scientific understanding of the Earth's climate system.

\section{References}

Ahrens, C. D. (2012). Essentials of meteorology: An invitation to the atmosphere, 6th Edition. Canada: Nelson Education Ltd.

Akbaş, Y. and Gençtürk, E. (2011). The effect of conceptual change approach to eliminate 9th grade high school students' misconceptions about air pressure. Educational Sciences: Theory and Practice, 11(4), 2217-2222.

Akengin, H. and Dölek, İ. (2013). Genel ve fiziki coğrafya, 1. Baskl, Ankara: Pegem Yayıncılık.

Akınoğlu, O. (2004). Yapılandırmacı öğrenme ve coğrafya öğretimi. Marmara Coğrafya Dergisi, 10, 73-94 https://dergipark.org.tr/download/article-file/3088

Akşit, F. (2007). Coğrafya öğretiminde aktif öğrenmenin akademik başarı ve tutum üzerine etkisi, Gazi Üniversitesi, Eğitim Bilimleri Enstitüsü, Coğrafya Eğitimi ABD, Yayınlanmamış doktora tezi.

Alkış, S. (2005). İlköğretim birinci kademe sosyal bilgiler ders kitaplarında coğrafya konularıla ilgili kavramların belirlenmesi (2004 programına göre). Marmara Coğrafya Dergisi, 11, 83-92.

Alkış, S. (2006). İlköğretim öğrencilerinin yağış kavramını algılama biçimleri. Elementary Education Online, 5(2), 126-140.

American Association for the Advancement of Science (AAAS) (2007). Communicating and learning about global climate change: An abbreviated guide for teaching climate change, 
Washington, DC: AAAS, p. 18. (Available at http://www.aaas.org/news/press_room/ climate_change/mtg_200702/climate_change_guide_2061.pdf

Arsal, Z. (2010). The greenhouse effect misconceptions of the elementary school teacher candidates. Elementary Education Online, 9(1), 229-240.

Artvinli, E. (2009). The level of the access to geographic skills in the 9. Year geography textbook according to geography curriculum. Erzincan Eğitim Fakültesi Dergisi, 11(2), 51-66.

Atalay, İ. (2004). Milli Eğitim Bakanlığı Ders Kitapları Dizisinde Yayımlanan Coğrafya Ders Kitapları Hakkında Düşünceler. I. Sosyal Bilgiler Eğitim Kongresi (15-17 Mayıs 2003 İzmir) Tebliğler, Ankara.

Atalay, İ. (2013). Uygulamalı Klimatoloji, İzmir: Meta Basın.

Başıüyük, A., Doğar, Ç., Gürses, A. \& Yazıcı, H. (2004). Yüksek öğrenim öğrencilerinin hava ve iklim olaylarını anlama seviyeleri ve kavram yanılgıları, Milli Eğitim Dergisi, 162, 255-270.

Bell, B., (2005). Constructivist view of learning. Learning in Science: The Waikato Research, B. Bell, Ed., Routledge Falmer, 17-38.

Boyes, E. D., and Stanisstreet, M. (1992). Students' perceptions of global warming. International Journal of Environmental Studies, 42(4), 287-300.

Boyes, E., Chambers, W., and Stanisstreet, M. (1995). Trainee primary teachers' ideas about the ozone layer. Some recommendations for teaching. Environmental Education_Research, 1(2), 133-145.

Bozkurt, O. \& Cansüngü, Ö. (2002). İlköğretim öğrencilerinin sera etkisi ile ilgili kavram yanılgıları. H. Ü. Ĕgitim Fakültesi Dergisi, 23, 67-73.

Chang, C.H., Pascua, L. and Ess, F. (2018). Closing the "Hole in the Sky": The Use of Refutation-Oriented Instruction to Correct Students' Climate Change Misconceptions, Journal of Geography, 117:1, 3-16, DOI: 10.1080/00221341.2017.1287768

Choi, S., Niyogi, D. Shepards, P.D. and Charusombat, U. (2010). Do earth and environmental science textbooks promote middle and high school students' conceptual development about climate change? Textbooks' consideration of students' misconceptions, Bulletin of the American Meteorological Society, 7: 889-898 (Available online at http://landsurface.itap.purdue.edu/publications-protected/J95.pdf)

Cohen, L., Manion, L. and Morrison, K. (2004). A Guide to Teaching Practice, 5.Edition, London and Newyork: Routledgefalmer

Corbin, J. and Strauss, A. (2008). Basics of qualitative research: Techniques and procedures for developing grounded theory (3rd ed.). Thousand Oaks, CA: Sage.

Coşkun M, (2003). Coğrafya öğretiminde nem konusundaki kavram yanlışlıkları ve giderilmesine yönelik öneriler. Gazi Eğitim Fakültesi Dergisi, 23(3), 147-158.

Demiralp, N. (2007). Coğrafya eğitiminde materyaller ve 2005 coğrafya dersi öğretim programı, Kastamonu Ĕgitim Dergisi, 15(1), 373-384 
Bozkurt, F. (2019) / Evaluation of Geography Textbooks in Terms of Misconceptions about Climate....

Demirkaya, H. (2008). Sınıf öğretmeni adaylarının küresel isınma kavramın algılamaları ve ögrenme stilleri: Fenomenografik bir analiz. Kuram ve Uygulamada Eğitim Bilimleri Dergisi, 8(1), 33-58.

Doğanay, H. \& Sever, R. (2011).Genel ve fiziki coğrafya, 9. Baskı, Ankara: Pegem Yayıncılık.

Doğar, Ç. \& Başıbüyük, A. (2005). İlköğretim ve ortaöğretim öğrencilerinin hava ve iklim olaylarını anlama düzeyleri. Kastamonu Ĕgitim Dergisi, 13(2), 347-358.

Duman, B. \& Atar, E. (2004). Data show teknolojisinin coğrafya dersinde soyut konuların öğretilmesinde öğrencilerin akademik başarısı ve motivasyonu üzerindeki etkisi. The Turkish Online Journal of Educational Technology, 3(4).

Erol, O. (2011). Genel Klimatoloji, İstanbul: Çantay Yayıncılık.

Fraser, A.B. (2007). Bad meteorology. http://www.ems.psu.edu/ fraser/BadMeteorology.html.

Gautier, C., Deutsch, K., and Rebich, S. (2006). Misconceptions about the greenhouse effect. Journal of Geoscience Education, 54(3), 386-395. Retrieved from http://www.nagt.org/files/nagt/jge/abstracts/gautierv54p386.pdf

Gökçe, N. (2009). The problems of geography education and some suggestions. Kuram ve Uygulamada Eğitim Bilimleri, 9(2), 757-768

Gowda, M., Fox, J., and Magelky, R. (1997). Students' understanding of climate change: Insights for scientists and educators. Bulletin of the American Meteorological Society, $78(10), 2232-2240$.

Hansen, P.J.K. (2003). The greenhouse effect and the effects of the ozone layer: Norwegian teacher students' development of knowledge and teaching skills. VI International Conference on School and Popular Meteorological and Oceanographic Education, Departamento de Física, Universidad Europea de Madrid, Spain.

Henriques, L. (2002). Children's misconceptions about weather: a review of the literature. School Science and Mathematics, 102(5), 202-209.

Hess, D. and Tasa, G. D. (2014). McKnight's physical geography: A landscape appreciation (11th Edition), USA: Pearson Education, Inc.

Kahraman, S., Yalçın, M., Özkan, E. and Aggul, F. (2008). Sınıf öğretmenliği öğrencilerinin küresel isınma konusundaki farkındalıkları ve bilgi düzeyleri. GÜ, Gazi Eğitim Fakültesi Dergisi, 28(3), 249-263.

Khalid, T. (2001). Pre-service teachers' misconceptions regarding three environmental issues. Canadian Journal of Environmental Education, 6, 102-120.

Kılınç, A., Stanisstreet, M. and Boyes, E. (2008). Turkish students' ideas about global warming. International Journal of Environmental and Science Education, 3(2), 89-98.

Kışoğlu, M., Gürbüz, H., Erkol, M., Akar, S. M. and Akıllı, M. (2010). Prospective Turkish elementary science teachers' knowledge level about the greenhouse effect and their views on environmental education in university. International Electronic Journal of Elementary Education, 2(2), 217-236.

Lightman, A., and Sadler, P. (1988). The earth is round? Who are you kidding? Science and Children, 25, 24-6.

Mattingly, R. L. (1987). The dynamics of flowing water. Science Teacher, 54, 22-27. 
McCaffrey, M. and Buhr, S. (2008). Clarifying climate confusion: Addressing systemic holes, Cognitive gaps, and misconceptions through climate literacy. Physical Geography, 29(6), $512-528$.

National Research Council (1990). Fulfilling the promise: Biology education in the nation's schools. Washington, DC: National Academies Press.

Nelson, B.D., Aron, R.H. and Francek M.A. (1992). Clarification of selected misconceptions in, physical geography. Journal of Geography, 91(2), 76-80.

Paradis, T. W., and Dexter, L. R. (2007). Learner-centered teaching and assessment in an undergraduate field analysis course. Journal of Geography, 106(4), 171-180.

Pınar, A. and Akdağ, H. (2012). Social studies teacher trainees' comprehension level of climate, wind, temperature, precipitation, erosion, ecology and map concepts. Elementary Education Online, 11(2), 530 -542

Rebich, S. and Gautier, C. (2005) Concept mapping to reveal prior knowledge. Journal_of Geoscience Education, 53(4), 355-365.

Román, D. and Busch, K.C. (2015). Textbooks of doubt: using systemic functional analysis to explore the framing of climate change in middle-school science textbooks, Environmental Education Research, 22(8), 1158-1180. DOI: 10.1080/13504622.2015.1091878

Şahin, C. (2001). Ortaöğretim coğrafya öğretmenlerinin mesleki sorunları hakkında bir araştırma. Marmara Coğrafya Dergisi, 13(2), 59-70

Şahin, C. (2003). Türkiye'de coğrafya öğretimi, sorunlarl ve çözüm önerileri (2. baskl). Ankara: Gündüz Eğitim ve Yayıncılık.

Şahin, C. (2006). Ideas and suggestions about the training program of geography lesson prepared by the ministry of national education in the year of 2005. Gazi Eğitim Fakültesi Dergisi, 26(3), 279-304.

Schneps, P. and Sadler, P. (1985). A Private Universe: Cambridge, MA, Harvard-Smithsonian Center for Astrophysics, Science Education Department. Retrieved from http://www.learner.org/teacherslab/pup/

Sekin, S. \& Ünlü, M. (2002). Coğrafya dersinin temel öğretim sorunları. Marmara Coğrafya Dergisi, 5, 43-53.

Smolkin, L., McTigue, E. M. and Yeh, Y. (2011). Searching for explanations in science trade books: What can we learn from coh-metrix? International Journal of Science Education, 35(8), 1367-1384.

Strahler, A. (2013). Introducing physical geography, Sixth Edition, USA: John Wiley and Sons, Inc.

Turan, İ, (2002). Lise coğrafya derslerinde kavram ve terim öğretimi ile ilgili sorunlar. G. Gazi Eğitim Fakültesi Dergisi, 22(2), 67-84.

Türkeş, M. (1997). Hava ve iklim kavramları üzerine. TÜBİTAK Bilim ve Teknik Dergisi, 355, 36-37, Ankara.

Ünlü, İ., Sever, R. and Akpınar, E. (2011). Türkiye'de çevre eğitimi alanında yapılmış küresel 1sınma ve sera etkisi konulu akademik araştırmaların sonuçlarının incelenmesi. Erzincan Eğitim Fakültesi Dergisi, 13(1), 39-54. 
Yıldırım, A. \& Şimşek, H. (2013). Sosyal Bilimlerde Nitel Araştırma Yöntemleri. Ankara: Seçkin Yayıncılık.

Zaman, S. (2017). Coğrafya 9. Sinıf ders kitabl. Milli Eğitim Bakanlı̆̆ı Yayınları http://www.eba.gov.tr/ekitap?andsearch=co\%C4\%9Frafya

\section{Biographical statement}

Fisun Bozkurt is an assistant professor of Social Studies Education Department at the University of Pamukkale in Turkey. Her academic interests lie within the broad area of innovative teaching approaches and alternative assessment methods. 